\title{
Study of the Micrococcaceae and Staphylococcaceae throughout the Manufacture of Dry-Cured Lacón (a Spanish Traditional Meat Product) Made without or with Additives
}

\author{
José M. Lorenzo, María C. García Fontán, María Gómez, Sonia Fonseca, \\ Inmaculada Franco \& Javier Carballo (corresponding author) \\ Área de Tecnología de los Alimentos, Facultad de Ciencias de Ourense \\ Universidad de Vigo, Ourense 32004, Spain \\ Tel.: 34-988-387-052 E-mail: carbatec@uvigo.es
}

Received: December 2, 2011

Accepted: December 16, $2011 \quad$ Published: February 1, 2012

doi:10.5539/jfr.v1n1p200

URL: http://dx.doi.org/10.5539/jfr.v1n1p200

This research was supported by the Xunta de Galicia (The Regional Government) (Projects $38301 B 98$ and PGIDT01PXI38301PR). José M. Lorenzo was supported by a Pre-doctoral fellowship from the Xunta de Galicia.

\begin{abstract}
Micrococcaceae and Staphylococcaceae were enumerated (on SPC agar $+7.5 \% \mathrm{NaCl}$ ) in samples from the surface and the interior of pieces of dry-cured lacón (a Spanish traditional meat product), at different stages of the manufacturing process, and from six different batches (three made without and three with additives -glucose, sodium nitrite, sodium nitrate, sodium ascorbate, and sodium citrate-). The use of additives did not affect the counts or evolution of this microbial group.

For four batches (two without and two with additives), a total of 335 strains were isolated and identified by classical methods.

Staphylococcus xylosus was the most abundant and constant species throughout manufacture of the batches made without and with additives. Other species of staphylococci were isolated, including: Staph. equorum, Staph. sciuri, Staph. gallinarum, Staph. cohnii, Staph. intermedius, Staph. capitis, Staph. epidermidis, Staph. simulans and Staph. warneri. Species of Micrococcus or Kocuria isolated in very low proportions, included Kocuria varians, $K$. rosea, Micrococcus lylae and M. luteus.
\end{abstract}

Keywords: Dry-cured lacón, Meat products, Micrococcaceae, Staphylococcaceae, Additives

\section{Introduction}

Dry-cured lacón is a traditional raw-cured meat product made in NW Spain, from the foreleg of the pig cut at the shoulder blade-humerus joint, following manufacturing processes similar to those used in the production of dry-cured ham. In the autonomous region of Galicia (NW Spain), the product is recognised as a Geographically Protected Identity (G.P.I.) (Official Journal of the European Communities, 2001).

Previous studies on dry-cured lacón have mainly concerned biochemical and sensory characterization of the final product (Marra et al., 1999; Veiga et al., 2003), as well as the biochemical changes that take place during the manufacturing process (Lorenzo et al., 2003; Lorenzo et al., 2008a; Lorenzo et al., 2008b). However, very few studies have explored the microbiological characteristics and refer only to the counts of some microbial groups at the end of the different stages of manufacture (Vilar et al., 2000). There is no information about the presence of microbial groups of technological interest or about the species that occur throughout the entire manufacturing process. This restricts the manufacturer's ability to control these microorganisms with the aim of improving the quality of the final product. Moreover, the product is traditionally manufactured with only coarse salt, and no other additives. Recently, manufacturers have begun to use some common additives with the aim of improving the appearance and quality of the final product (to develop the typical colour of cured meats and inhibit growth 
of moulds on the surface). The effect of these additives on the microbial populations present throughout the manufacturing process is at present unknown.

The importance of the microorganisms belonging to the Micrococcaceae and Staphylococcaceae families in the biochemical processes that take place during the ripening of raw-cured meat products has been demonstrated by several authors (Liepe, 1983; Hammes, 1986; Hinrichsen and Pedersen, 1995), who emphasized the contribution of these microorganisms to the development of the colour and flavour of the products. The main functions of these microorganisms in cured meat products are: (i) production of catalase, (ii) production of nitrite reductase, (iii) reduction of nitrate, (iv) production of proteases, peptidades and lipases, which intervene in the degradative processes that take place throughout maturation of the products and are responsible for the production of the taste and aroma compounds that characterize the flavour of the final products. After lactic acid bacteria, these microorganisms are the most often used as starter cultures in the meat industry. However, strains belonging to this microbial group can develop undesirable actions such as production of biogenic amines or enterotoxins dangerous to consumers.

The aims of the present work, which forms part of a wider study on the microbiological and biochemical changes that take place during the manufacture of dry-cured lacón, were to quantify the Micrococcaceae and Staphylococcaceae on the surface and in the interior of this meat product at different stages of the manufacturing process, to identify the species present, and also to study the effect of the use of some additives on the presence and behaviour of this microbial group. In future studies, the technological and safety properties of the isolated strains will be investigated in detail in order to determine the role of these species in the manufacture of lacón, with the final purpose of using these strains as starter cultures.

\section{Materials and Methods}

\subsection{Samples}

Six batches of dry-cured lacón were manufactured in three different pork meat industries. Each batch comprised 9 pieces of lacón (from Landrace x Large White pigs) each weighing approximately $4 \mathrm{~kg}$. Raw pieces from three batches, one per industry, were salted with an excess of coarse salt, to form piles with alternate layers comprising of pieces or salt. The pieces remained in the pile for four days (one day per $\mathrm{kg}$ of weight). The temperature of the salting room was between 2 and $5{ }^{\circ} \mathrm{C}$, and the relative humidity between 80 and $90 \%$. After the salting stage, the pieces were removed from the pile, brushed, washed and transferred to a post-salting room where they remained for 14 days at $2-5{ }^{\circ} \mathrm{C}$ and approximately $85-90 \%$ relative humidity. After the post-salting stage, the pieces were transferred to a room at $12{ }^{\circ} \mathrm{C}$ and $74-78 \%$ relative humidity, where drying-ripening took place over the course of 84 days. Prior to the salting process, the pieces from the other three batches (one per industry) were each rubbed with a mixture of additives comprising glucose $(2 \mathrm{~g} / \mathrm{kg})$, sodium nitrite $\left(\mathrm{E}_{250}\right)(125 \mathrm{mg} / \mathrm{kg})$, sodium nitrate $\left(E_{251}\right)(175 \mathrm{mg} / \mathrm{kg})$, sodium ascorbate $\left(E_{301}\right)(500 \mathrm{mg} / \mathrm{kg})$, and sodium citrate $\left(E_{331}\right)(100 \mathrm{mg} / \mathrm{kg})$. In these batches, salting, post-salting and drying-ripening were carried out under the same conditions as in the batches manufactured without additives.

In each batch, samples were taken from fresh pieces, after the end of the salting stage, after 7 and 14 days of post-salting, and after 7, 14, 28, 56, and 84 days of drying-ripening. Each sample consisted of one whole piece of lacón. Samples were transported to the laboratory at $<4^{\circ} \mathrm{C}$ and analysed on arrival.

\subsection{Microbiological analysis}

In each lacón piece, samples from the surface and interior were obtained for analysis. Surface samples were taken by aseptic removal of slices (surface area $100 \mathrm{~cm}^{2}$ and about $2 \mathrm{~mm}$ in thickness) following the method of Fliss et al. (1991). Samples from the interior were taken with the aid of a sterile metallic rod, which was introduced into the musculature at five different points, after aseptic and consecutive removal of three $2 \mathrm{~mm}$ thick slices from the surface. Twenty-five grams from the surface and 25 grams from the interior of each piece of lacón were homogenized, in each case with $100 \mathrm{~mL}$ sterile $0.1 \%$ peptone (Oxoid, Unipath Ltd., Basingstoke, UK) water containing $0.85 \% \mathrm{NaCl}$ and $1 \%$ Tween 80 as emulsifier, at $40-45{ }^{\circ} \mathrm{C}$ for 2 min in a Stomacher $400 \mathrm{Lab}$ Blender (Seward Medical, London, UK), to provide a 1/5 dilution. Successive tenfold dilutions were prepared by mixing $10 \mathrm{~mL}$ of the previous dilution with $90 \mathrm{~mL} 0.1 \%$ sterile peptone water.

In each sample, the Micrococcaceae and Staphylococcaceae were enumerated on Standard Plate Count Agar (Oxoid) $+7.5 \mathrm{NaCl}$, after incubation at $30^{\circ} \mathrm{C}$ for $48 \mathrm{~h}$.

From each sample, $1 \mathrm{~mL}$ of each dilution was inoculated in duplicate on plates and mixed before solidification. After incubation, the number of colonies on plates with 30-300 colonies, were counted. 


\subsection{Isolation and identification of strains}

For four batches (two made without and two made with additives), 10 colonies were taken at random from SPC agar $+7.5 \% \mathrm{NaCl}$ plates, from each sampling point corresponding to each batch (five from the surface sample and five from the interior sample) with the aid of a Harrison disk (Harrigan and Mc Cance, 1976). For some sampling points it was not possible to collect this number of colonies because of lack of growth or insufficient growth on the plates. Ninety strains were isolated from the surface and 80 from the interior of the pieces in the batches made without additives, and 90 strains were isolated from the surface and 75 from the interior of the pieces in the batches made with additives. The isolates were purified by 4 alternate subcultures on BHI agar and in BHI broth (Oxoid). The purified strains were then maintained at $-80{ }^{\circ} \mathrm{C}$ with $20 \%$ glycerol as a cryoprotective agent.

Gram-positive, catalase-positive cocci grouped in pairs, tetrads or irregular clusters were identified following the methods and criteria described by Schleifer and Kloos (1975a, 1975b), Schleifer (1986) and Kloos et al. (1992). The following tests were carried out on each isolate: oxidation and fermentation of glucose and mannitol; assimilation of glycerol in aerobic conditions; growth in furazolidone agar and growth in lysostaphin agar. The aerobic cocci that were resistant to furazolidone and lysostaphin and incapable of assimilating glycerol were considered to be Micrococcaceae; the facultatively anaerobic cocci, incapable of growth in furazolidone agar and lysostaphin agar and able to assimilate glycerol were considered to be Staphylococcaceae. In order to identify the strains to species level, the following tests were carried out: colony pigmentation on BHI agar; growth in 7.5, 10 and $15 \% \mathrm{NaCl}$; characteristics of growth in Baird-Parker agar; aesculin hydrolysis; growth at $10{ }^{\circ} \mathrm{C}$; acetoin production; nitrate reduction; presence of oxidase, alkaline phosphatase, urease, arginine dihydrolase, ornithine decarboxylase, ß-galactosidase, arginine arylamidase, pyrrolidonyl arylamidase, ß-glucuronidase; novobiocin resistance and acid production from $\mathrm{N}$-acetyl glucosamine, L-arabinose, D-cellobiose, D-fructose, glucose, glycerol, lactose, maltose, D-mannitol, D-mannose, raffinose, D-ribose, sucrose, D-trehalose and D-turanose.

Identity of the strains was confirmed using the system API 32 STAPH (bioMérieux, Marcy-l'Etoile, France).

\subsection{Biochemical analysis}

Total solid, $\mathrm{NaCl}$ and nitrate contents, and $\mathrm{pH}$ and $\mathrm{a}_{\mathrm{w}}$ values were determined using the methods cited by Lorenzo et al. (2003). All chemical determinations were carried out in duplicate in each sample.

\subsection{Statistical analysis}

In order to detect any significant differences between the different sampling points during ripening of the batches from the same manufacturing process (without or with additives), and between the two types of processes at each sampling time, analyses of variance (ANOVA) were performed, with a confidence interval of $95 \%(P<0.05)$. Means were compared by the least squares difference (LSD) test, with the Statistica ${ }^{\odot} 5.1$ computer programme for Windows (Statsoft Inc, 1996, Tulsa, OK, USA).

\section{Results and Discussion}

\subsection{Microbial counts throughout the manufacturing process}

Table 1 shows the changes in the counts in SPC agar $+7.5 \% \mathrm{NaCl}$ corresponding to the surface and the interior of the pieces, in the batches made without and with additives. This table also shows the counts of total aerobic mesophilic microflora on SPC agar (Oxoid), already published (Lorenzo et al., 2010), with the only purpose to show and to appreciate the contribution of the Micrococcaceae and Staphylococcaceae to the total aerobic mesophilic microflora in this meat product.

High counts of total aerobic mesophilic microflora and Micrococcaceae and Staphylococcaceae were observed, both at the surface and in the interior of the fresh pieces, which appears to be associated with appreciable contamination of the pieces and an important degree of microbial multiplication in the quartering rooms and in the manufacturing industries.

The counts of the Micrococcaceae and Staphylococcaceae at the surface of the fresh pieces were similar to those observed by Silla et al. (1989) and of the order of $0.5 \log _{10}$ units higher than those reported by Huerta et al. (1988) for fresh ham pieces. The counts of this microbial group in the interior of the fresh pieces were around one $\log _{10}$ unit lower than those observed by Huerta et al. (1988) in raw pieces used in the manufacture of raw-cured ham.

After salting, the counts of the Micrococcaceae and Staphylococcaceae at the surface showed a small decrease, sometimes even imperceptible. The decrease in numbers was more intense in the interior of the pieces. 
The Micrococcaceae and Staphylococcaceae increased significantly $(P<0.05)$ during the post-salting stage and during the first days of the drying-ripening stage, with maximum counts reached after 7 days of drying-ripening (around $9 \log _{10} \mathrm{CFU} / \mathrm{g}$ in the surface and 3-4 $\log _{10} \mathrm{CFU} / \mathrm{g}$ in the interior of the pieces); the microbial counts then remained stable until the end of the manufacturing process.

An increase in the counts of the salt tolerant microflora during the post-salting and the first days of the drying-ripening stage has also been observed by several authors during the manufacture of other raw-cured meat products made from whole pieces such as ham (Huerta et al., 1988; Silla et al., 1989; Carrascosa et al., 1992) and Spanish cecina (García et al., 1995).

Due to the intensity of the salting process in this meat product, and to the high salt concentrations reached both at the surface and in the interior of the pieces immediately after the post-salting stage (see Table 2), the counts of the Micrococcaceae and Staphylococcaceae from the end of the post-salting stage (14 days of post-salting) were almost the same as those of the total aerobic mesophilic microflora, as a consequence of the selective action exercised by the high $\mathrm{NaCl}$ contents. This effect has previously been observed in other meat products subjected to salting followed by a drying-ripening process (Giolitti et al., 1971; Graham and Blumer, 1971; Van der Riet, 1982; Carrascosa et al., 1988; Huerta et al., 1988; Silla et al., 1989; Rodríguez et al., 1994; García et al., 1995).

At each stage of manufacture, comparison of the average counts of the Micrococcaceae and Staphylococcaceae corresponding to the surface and the interior of the pieces of the batches made without additives with those obtained in the pieces of the batches made with additives, revealed that the use of additives had little effect on the growth of this microbial group.

\subsection{Species isolated throughout the manufacturing process}

Of the 90 strains isolated from the surface of the pieces from the batches made without additives, 52 were identified as Staphylococcus xylosus, 5 as Staph. equorum, 1as Staph. warneri, 1 as Staph. epidermidis, 7 as Staph. intermedius, 2 as Staph. capitis, 2 as Staph. sciuri, 1 as Staph. gallinarum, 2 as Kocuria varians, 1 as M. lylae, 11 did not belong to the Micrococcaceae or Staphylococcaceae families and 5 strains were lost in the course of the purification process.

The distribution in the sampling points of the species isolated from the surface of the pieces during the manufacture of the lacón batches made without additives is shown in Table 3.

Of the 80 strains isolated from the interior of the pieces from the batches made without additives, 56 were identified as Staphylococcus xylosus, 3 as Staph. equorum, 2 as Staph. simulans, 1 as Staph. intermedius, 1 as Staph. capitis, 1 as Staph. cohnni, 1 as Staph. gallinarum, 2 as Kocuria varians, 1 as K. rosea, 11 did not belong to the Micrococcaceae or Staphylococcaceae families and one strain was lost during the course of the purification process.

The distribution in the sampling points of the species isolated from the interior of the pieces during the manufacture of the lacón batches made without additives is also shown in Table 3.

Of the 90 strains isolated from the surface of the pieces from the batches made with additives, 56 were identifed as Stahylococcus xylosus, 4 as Staph. equorum, 2 as Staph. warneri, 3 as Staph. epidermidis, 4 as Staph. intermedius, 5 as Staph. capitis, 3 as Staph. sciuri, 1 as Micrococcus luteus, 1 as K. varians, 1 as K. rosea, 6 strains did not belong to the Micrococcaceae or Staphylococcaceae families and 4 strains were lost during the course of the purification process.

The distribution in the sampling points of the species isolated from the surface of the pieces during the manufacture of the lacón batches made with additives is shown in Table 4.

Of the 75 strains isolated from the interior of the pieces from the batches made with additives, 51 were identified as Staphylococcus xylosus, 2 as Staph. equorum, 1 as Staph. simulans, 5 as Staph. intermedius, 1 as Staph. capitis, 1 as Staph. cohnni, 1 as Staph. sciuri, 1 as Kocuria varians, 9 strains did not belong to the Micrococcaceae or Staphylococcaceae families and 3 strains were lost during the course of the purification process.

The distribution in the sampling points of the species isolated from the interior of the pieces during the manufacture of the lacón batches made with additives is also shown in Table 4.

Of the 335 strains isolated in the present study during the manufacture of the four lacón batches, 322 strains were identified ( 13 were lost during the purification process). Of these 322 strains, 285 were identified as Micrococcaceae (genera Micrococcus and Kocuria) or Staphylococcaceae (genus Staphylococcus) (88\% of the 
strains subjected to identification), which reflects the high selectivity of the SPC agar $+7.5 \%$ of $\mathrm{NaCl}$ medium for this microbial group.

In the present study, many more isolates were identified as Staphylococcaceae (genus Staphylococcus) than as Micrococcaceae (genera Micrococcus and Kocuria). The Staphylococcus strains comprised 95.9\% of the strains identified from the surface of the pieces made without additives, $95.6 \%$ of the strains identified from the interior of the pieces made without additives, $96.25 \%$ of the strains identified from the surface of the pieces made with additives, and $98.4 \%$ of the strains identified from the interior of the pieces made with additives. The Micrococcus/Kocuria only comprised $4.0 \%, 4.4 \%, 3.75 \%$ and $1.6 \%$ of the strains identified, respectively.

The predominance of the isolates of the genus Staphylococcus over those of the genera Micrococcus or Kocuria is a common finding in studies of characterization of the microflora of meat products (Graham and Blumer, 1971; Von Rheinbaben and Seipp, 1986; Molina et al., 1989; Comi et al., 1992; Kotzekidou, 1992; Delarras et al., 1994; Rodríguez et al., 1994; García et al., 1995; Rodríguez Jovita, 1997; Papamanoli et al., 2002; Martín et al., 2006). This same phenomenon has been observed by Delarras et al. (1994) in different raw foods of animal origin.

The prevalence of the genus Staphylococcus may be at least partly due to the greater resistance to high concentrations of salt that the staphylococci show, in addition to their wider distribution in nature. The Staphylococcus grow in the presence of salt contents of up to $15 \%$, while the Micrococcus cannot tolerate concentrations of more than approximately 10\% (Seager et al., 1986; Campanini et al., 1987; Kotzekidou, 1992). The best adaptation of the Staphylococcus to the low values of redox potential that become established as consequence of the drying of the product may affect this phenomenon (Kotzekidou, 1992). The percentage of Staphylococcus and of Micrococcus in particular products varies depending on the salt content and on the values of $\mathrm{a}_{\mathrm{w}}$ and $\mathrm{Eh}$; variations in $\mathrm{pH}$ do not appear to affect this percentage.

In general the same species of Staphylococcus and of Micrococcus/Kocuria were isolated from the batches made without and with additives.

Staphylococus xylosus was the most abundant and most consistent species throughout the manufacture of the batches made without and with additives, and prevailed as much in the surface as in the interior of the pieces. This species comprised $73 \%$ of the strains of staphylococci isolated from the surface of the pieces in the batches made without additives, $86 \%$ of those isolated from the interior of the pieces in the batches made without additives, $73 \%$ of those isolated from the surface of the pieces in the batches made with additives, and $82 \%$ of those isolated from the interior of the pieces in the batches made with additives. This species has also been identified as the most abundant species of Staphylococcus in other raw-cured meat products made from whole pieces (Von Reinbaben and Seipp, 1986; Molina et al., 1989; Carrascosa and Cornejo, 1991; Cornejo and Carrascosa, 1991; Rodríguez et al., 1994) and in fermented sausages (Seager et al., 1986; Coppola et al., 2000; Cocolin et al., 2001; Papamanoli et al., 2002; Rantsiou et al., 2005; Martín et al., 2006; García Fontán et al., 2007b; Martín et al., 2007). This species is, in fact, one of the most resistant to unfavourable environmental conditions (McMeekin et al., 1987; Chandler and McMeekin, 1989). Staphylococcus xylosus is also one of the most genetically variable microbial species, which may lead to the existence of diverse biotypes with different phenotypic characteristics (Kloos, 1980); this phenomenon may be due to the capacity of this species to adapt to different environmental conditions (Rodríguez Jovita, 1997). Some authors have proposed preparing a starter culture with this species in order to ensure good development of the process for ham, as well as for other raw-cured meat products (Hammes et al., 1985; Lücke and Hechelmann, 1987).

Among the novobiocin-resistant species of staphylococci, Staph. equorum was the next most abundant, although present in much smaller proportion than Staph. xylosus. This species was isolated equally from the batches made without additives and from those made with additives, and from the surface and the interior of the pieces. Staphylococcus equorum was the main species of staphylococci isolated from Spanish cecina (García et al., 1995) and has also been isolated by different authors in other raw-cured meat products made from whole pieces (Cornejo and Carrascosa, 1991; Kotzekidou, 1992; Rodríguez et al., 1994; Rodríguez Jovita, 1997), and from fermented sausages (Cantoni and Pizzo, 1980; Simonetti and Cantoni, 1983; Comi et al., 1986; Seager et al., 1986; García Fontán et al., 2007b). Staphylococus equorum is, along with Staph. xylosus, one of the most abundant species in fresh meat (Schleifer et al., 1984; Kloos, 1990).

Staphylococcus sciuri was isolated in very low numbers and was not isolated from the samples of the interior of the pieces in the batches made without additives. This species is, like Staph. xylosus, one of the species of staphylococci that is isolated in highest proportions at different stages of the process of manufacture of ham (Von Rheinbaben and Seipp, 1986; Molina et al., 1989). This species has also been isolated from sausages (García Fontán et al., 2007a), but in a very low proportion. 
Finally, among the novobiocin-resistant species of staphylococci, Staph. gallinarum and Staph. cohnii were isolated in very low proportions (only two strains of each species).

Among the species of staphylococci sensitive to novobiocin, the most abundant was Staph. intermedius (17 strains). This species was obviously much less abundant than Staph. xylosus, but it was isolated equally from the surface and from the interior of the pieces in the batches made without or with additives. Staphylococcus intermedius has so far not been identified in raw-cured meat products made from whole pieces, but it has been isolated from raw-cured sausages (Comi et al., 1992; García-Varona et al., 2000). The other novobiocin-sensitive species of staphylococci isolated in the present study were Staph. capitis (9 strains), Staph. epidermidis (4 strains), Staph. simulans (3 strains) and Staph. warneri (3 strains). The finding of these four species is consistent with the novobiocin-sensitive species of staphylococci isolated by other authors in other meat products (Delarras, 1980; Kloos et al., 1992; Martín et al., 2006). The proportions in which the latter authors isolated the species were also low and very similar to those found in the present study.

The salt used to cure the product is generally accepted to be the source of species of novobiocin-resistant staphylococci. In a study of isolates of Staphylococcus originating from marine salt and from salt previously used in the salting process of hams from white or Iberian pigs, Cordero and Zumalacárregui (2000) found Staph. xylosus and Staph. equorum to be the main species of staphylococci in the three types of salt. However these species may also originate from other types of contamination, since they are widespread in nature and comprise part of the normal flora of the skin of many farm animals; in fact, in recent studies (Leroy et al., 2006; Corbière Morot-Bizot et al., 2010) Staph. equorum was described as the most prevalent species of staphylococci in the environment of small units manufacturing traditional sausages. The presence of these species in the samples from the interior of the cured meat pieces is generally associated with the salt that penetrates the pieces. The microorganisms may therefore originate from the salt or may be present as superficial contaminants in the pieces.

The novobiocin-sensitive species originated from contamination from the skin of humans and the animals themselves (Schleifer, 1986; Comi et al., 1992). This microbial group has been isolated preferably from human skin (Kloos and Musselwhite, 1975; Kloos, 1990) and its presence in meat products has been related to handling of the pieces prior to the salting process. However, some of the novobiocin-sensitive species of staphylococci isolated in the present study (Staph. intermedius, Staph. capitis, Staph. epidermidis and Staph. simulans) were also isolated by Cordero and Zumalacárregui (2000) from salt, after hams were subjected to the salting process, although these authors suggest that the species may have originated from human sources. Judging from the identity of the species of staphylococci isolated from the lacón and from their proportions, it appears that salt is the main source of these microorganisms.

As already pointed out, microorganisms belonging to the Micrococcaceae family (genera Micrococcus and Kocuria) were isolated in very low proportions relative to those of the family Staphylococcaceae; the species isolated were: Kocuria varians (6 strains), K. rosea (2 strains), Micrococcus lylae (1 strain) and M. luteus (1 strain).

According to Schleifer et al. (1984), Kocuria varians is the predominant species of animal origin. Other authors have also isolated this species from other raw-cured meat products made from whole pieces (Van der Riet, 1982; Kotzekidou, 1992; García et al., 1995) and from fermented sausages (Papamanoli et al., 2002; Martín et al., 2006; García Fontán et al., 2007b), although also in very low proportions. This species is included among the starter cultures used in raw meat products (Lücke and Hechelmann, 1987).

Kocuria rosea has not been described in raw-cured meat products made from whole pieces, but it has been observed, although in very low proportions, in raw-cured sausages (Coppola et al., 1997) and in foods of animal origin (Delarras et al., 1994). It is present in soil and water (Schleifer, 1986), and its presence in dry-cured lacón may be associated with contamination of this origin.

One strain of Micrococcus luteus was isolated from the surface of one piece manufactured with additives. Isolation of M. luteus is not common in raw-cured meat products. This species dominates on the human skin (Kloos et al., 1974) and its presence in the lacón may be associated with handling of the pieces, although this species was also isolated by Cordero and Zumalacárregui (2000) from salt originating from the salting of hams from white pig.

Micrococcus lylae has been isolated by De la Rosa et al. (1990) in semi-preserved meat products, by García Fontán et al. (2007b) in fermented sausages, and by Cordero and Zumalacárregui (2000) from salt from the salting process of hams from white and Iberian pigs. Its origin also appears to be associated with handling of the pieces since this species is habitually present on human skin (Kloos et al., 1974). 


\section{References}

Campanini, M., Mutti, P., \& Previdi, P. (1987). Caratterizzazione di Micrococcaceae da insaccati stagionati. Industria Conserve, 62, 3-6.

Cantoni, C., \& Pizzo, P. (1980). Stafilococchi coagulasi negativi negli insaccati. Industrie Alimentari, 19, 99-101.

Carrascosa, A. V., \& Cornejo, I. (1991). Characterization of Micrococcaceae strains selected as potential starter cultures to Spanish dry cured ham process. 2. Slow process. Fleischwirtschaft, 71, 1187-1188.

Carrascosa, A. V., Cornejo, I., \& Marín, M.E. (1992). Vorkommem und Verteilung von Mikroorganismen auf der Oberflaeche trocken gepoekelter Spanischer Schinken. Fleischwirtschaft, 72, 1035-1038.

Carrascosa, A. V., Marín, M. E., Avendaño, M. C., \& Cornejo, I. (1988). Jamón serrano. Cambios microbiológicos y físico-químicos durante el curado rápido. Alimentaria, 194, 9-12.

Chandler, R. E., \& McMeekin, T. A. (1989). Modelling the growth response of Staphylococcus xylosus to changes in temperature and glycerol concentration/water activity. Journal of Applied Bacteriology, 66, 543-548. http://dx.doi.org/10.1111/j.1365-2672.1989.tb04576.x

Cocolin, L., Manzano, M., Aggio, D., Cantoni, C., \& Comi, G. (2001). A novel polymerase chain reaction (PCR)-Denaturing gel electrophoresis (DGGE) for the identification of Micrococcaceae strains involved in meat fermentations. Its application to naturally fermented Italian sausages. Meat Science, 57, 59-64. http://dx.doi.org/10.1016/S0309-1740(00)00131-5.

Comi, G., Cantoni, C., \& Celori, F. (1986). Consideracioni sugli stafilococchi coagulasi negativi degli insaccati crudi stagionati. Industrie Alimentari, 25, 378-381.

Comi, G., Citterio, B., Manzano, M., Cantoni, C., \& De Bertoldi, M. (1992). Evaluation and characterization of Micrococcaceae strains in Italian dry fermented sausages. Fleischwirtschaft, 72, 1693-1697.

Coppola, R., Iorizzo, M., Saotta, R., Sorrentino, E., \& Grazia, L. (1997). Characterization of micrococci and staphylococci isolated from soppressata molisana, a Southern Italy fermented sausage. Food Microbiology, 14, 47-53. http://dx.doi.org/10.1006/fmic.1996.0062.

Coppola, S., Mauriello, G., Aponte, M., Moschetti, G., \& Villani, F. (2000). Microbial succession during ripening of Naples-type salami, a southern Italian fermented sausage. Meat Science, 56, 321-329. http://dx.doi.org/10.1016/S0309-1740(00)00046-2

Corbière Morot-Bizot, S., Leroy, S., \& Talon, R. (2006). Staphylococcal community of a small unit manufacturing traditional dry fermented sausages. International Journal of Food Microbiology, 108, 210-217. http://dx.doi.org/10.1016/j.ijfoodmicro.2005.12.006.

Cordero, M. R., \& Zumalacárregui, J. M. (2000). Characterization of Micrococcaceae isolated from salt used for Spanish dry-cured ham. Letters in Applied Microbiology, 31, 303-306. http://dx.doi.org/10.1046/j.1472-765X.2000.00818.x.

Cornejo, I., \& Carrascosa, A. V. (1991). Characterization of Micrococcaceae strains selected as potential starter cultures in Spanish dry cured ham process. I. Fast process. Fleischwirtschaft, 71, 66-68.

De la Rosa, M. C., Mohino, M. R., Mohino, M., \& Mosso, M. A. (1990). Characteristics of micrococci and staphylococci isolated from semi-preserved meat products. Food Microbiology, 7, 207-215. http://dx.doi.org/10.1016/0740-0020(90)90026-E

Delarras, C. (1980). Numerical taxonomy of Micrococcaceae strains of meat product origin. Fleischwirtschaft, 60, 2207-2208, 2233-2235.

Delarras, C., Guichaoua, C., \& Caprais, M. P. (1994). Identification of 129 Micrococcaceae strains isolated from food of animal origin. Fleischwirtschaft, 74, 1084-1086.

Fliss, I., Simard, R. E., \& Etriki, A. (1991). Comparison of three sampling techniques for microbiological analysis of meat surface. Journal of Food Science, 56, 249-250. http://dx.doi.org/10.1111/j.1365-2621.1991.tb08021.x

García I., Zumalacárregui, J. M., \& Díez, V. (1995). Microbial succession and identification of Micrococcaceae in dried beef cecina, an intermediate moisture meat product. Food Microbiology, 12, 309-315. http://dx.doi.org/10.1016/S0740-0020(95)80111-1 
García Fontán, M. C., Lorenzo, J. M., Martínez, S., Franco, I., \& Carballo, J. (2007a). Microbiological characteristics of Botillo, a Spanish traditional pork sausage. LWT-Food Science and Technology, 40, 1610-1622. http://dx.doi.org/10.1016/j.lwt.2006.10.007.

García Fontán, M. C., Lorenzo, J. M., Parada, A., Franco, I., \& Carballo, J. (2007b). Microbiological characteristics of "androlla", a Spanish traditional pork sausage. Food Microbiology, 24, 52-58. http://dx.doi.org/10.1016/j.fm.2006.03.007.

García-Varona, M., Santos, E. V., Jaime, I., \& Rovira, J. (2000). Characterisation of Micrococcaceae isolated from different varieties of chorizo. International Journal of Food Microbiology, 54, 189-195. http://dx.doi.org/10.1016/S0168-1605(99)00192-0.

Giolitti, G., Cantoni, C., Bianchi, M., \& Renon, P. (1971). Microbiology and chemical changes in raw ham of Italian type. Journal of Applied Bacteriology, 34, 51-61. http://dx.doi.org/10.1111/j.1365-2672.1971.tb02268.x

Graham, P. P., \& Blumer, T. N. (1971). Bacterial flora prefrozen dry-cured ham at three processing time periods and its relationship to quality. Journal of Milk and Food Technology, 34, 586-592.

Hammes, W. P. (1986). Starter culture in meat production. Chemie, Mikrobiologie, Technologie der Lebensmittel, 9, 131-143.

Hammes, W. P., Rölz, S., \& Bautleon, A. (1985). Microbiological examination of starter culture preparations available on the German market for the production of dry sausage. Fleischwirtschaft, 65, 729-734.

Harrigan, W. F., \& Mc Cance, M. E. (1976). Statistical methods for the selection and examination of microbial colonies. In W.F. Harrigan, \& M.E. Mc Cance (Eds.). Laboratory Methods in Foods and Dairy Microbiology (pp. 47-49). London: Academic Press.

Hinrichsen, L. L., \& Pedersen, S. B. (1995). Relationship among flavor, volatile compounds, chemical changes and microflora in Italian-type dry-cured ham during processing. Journal of Agricultural and Food Chemistry, 43, 2932-2940. http://dx.doi.org/10.1021/jf00059a030

Huerta, T., Hernández, J., Guamis, B., \& Hernández, E. (1988). Microbiological and physico-chemical aspects in dry-salted Spanish ham. Zentralbl. Mikrobiol., 143, 475-482.

Kloos, W. E., Tornabene, T. G., \& Schleifer, K. H. (1974). Isolation and characterization of micrococci from human skin, including two new species: Micrococcus lylae and M. kristinae. International Journal of Systematic Bacteriology, 24, 79-101. http://dx.doi.org/10.1099/00207713-24-1-79

Kloos, W. E., \& Musselwhite, M. J. (1975). Distribution and persistence of Staphylococcus and Micrococcus species and other aerobic bacteria on human skin. Applied and Environmental Microbiology, 30, 381-395.

Kloos, W. E. (1980). Natural populations of the genus Staphylococcus. Annual Review of Microbiology, 34, 559-592. http://dx.doi.org/10.1146/annurev.mi.34.100180.003015

Kloos, W. E. (1990). Systematics and the natural history of staphylococci. Journal of Applied Bacteriology Symp. Suppl., 19, 25S-37S. http://dx.doi.org/10.1111/j.1365-2672.1990.tb01795.x

Kloos, W. E., Schleifer, K. H., \& Götz, F. (1992). The genus Staphylococcus. In A. Balows, H.G. Trüper, M. Dworkin, W. Harder, \& K.H. Schleifer (Eds.). The prokaryotes, second ed. (pp. 1369-1420). New York: Springer-Verlag Inc.

Kotzekidou, P. (1992). Identification of staphylococci and micrococci isolated from an intermediate moisture meat product. Journal of Food Science, 57, 249-251.

Leroy, S., Giammariano, P., Chacornac, J. P., Lebert, I., \& Talon, R. (2010). Biodiversity of indigenous staphylococci of naturally fermented dry sausages and manufacturing environments of small scale processing units. Food Microbiology, 27, 294-301. http://dx.doi.org/10.1016/j.fm.2009.11.005.

Liepe, H. U. (1983). Food and feed products with microorganisms. In H.J. Relm, \& G. Reed (Eds.). Biotechnology (pp. 399-424). Weinheim, Germany: Verlag Chemie GMBH.

Lorenzo, J. M., Prieto, B., Carballo, J., \& Franco, I. (2003). Compositional and degradative changes during the manufacture of dry-cured "lacón". Journal of the Science of Food and Agriculture, 83, 593-601. http://dx.doi.org/10.1002/jsfa.1375.

Lorenzo, J. M., García Fontán, M. C., Franco, I., \& Carballo, J. (2008a). Proteolytic and lipolytic modifications during the manufacture of dry-cured lacón, a Spanish traditional meat product: Effect of some additives. Food Chemistry, 110, 137-149. http://dx.doi.org/10.1016/j.foodchem.2008.02.002. 
Lorenzo, J. M., García Fontán, M. C., Franco, I., \& Carballo, J. (2008b). Biochemical characteristics of dry-cured lacón (a Spanish traditional meat product) throughout the manufacture, and sensorial properties of the final product. Effect of some additives. Food Control, 19, 1148-1158. http://dx.doi.org/10.1016/j.foodcont.2007.12.005.

Lorenzo J. M., García Fontán, M. C., Cachaldora, A., Franco, I., \& Carballo, J. (2010). Study of the lactic acid bacteria throughout the manufacture of dry-cured lacón (a Spanish traditional meat product). Effect of some additives. Food Microbiology, 27, 229-235. http://dx.doi.org/10.1016/j.fm.2009.10.003.

Lücke, F. K., \& Hechelmann, H. (1987). Starter cultures for dry sausages and ham: composition and effect. Fleischwirtschaft Español, 67, 307-314.

Martín, A., Colín, B., Aranda, E., Benito, M. J., \& Córdoba, M. G. (2007). Characterization of Micrococcaceae isolated from Iberian dry-cured sausages. Meat Science, 75, 696-708. http://dx.doi.org/10.1016/j.meatsci.2006.10.001.

Martín, B., Garriga, M., Hugas, M., Bover-Cid, S., Veciana-Nogués, M. T., \& Aymerich, T. (2006). Molecular, technological and safety characterization of Gram-positive, catalase-positive cocci from slightly fermented sausages. International Journal of Food Microbiology, 107, 148-158. http://dx.doi.org/10.1016/j.ijfoodmicro.2005.08.024.

Marra, A. I., Salgado, A., Prieto, B., \& Carballo, J. (1999). Biochemical characteristics of dry-cured lacón. Food Chemistry, 67, 33-37. http://dx.doi.org/10.1016/S0308-8146(99)00104-1.

McMeekin, T. A., Chandler, R. E., Doe, P. E., Garland, C. D., Olley, J., Putro, S., \& Ratkowsky, D. A. (1987). Model for combined effect of temperature and salt concentration/water activity on the growth rate of Staphylococcus xylosus. Journal of Applied Bacteriology, 62, 543-550.

Molina, I., Silla, H., Flores, J., \& Monzo, J. L. (1989). Study of the microbial flora in dry cured ham. II. Micrococcaceae. Fleischwirtschaft, 69, 1433-1434.

Official Journal of the European Communities (2001). Commission Regulation (EC) No 898/2001 of 7 May 2001. L 126, vol 44, 8, May 2001, p. 18.

Papamanoli, E., Kotzekidou, P., Tzanetakis, N., \& Litopoulou-Tzanetaki, E. (2002). Characterization of Micrococcaceae isolated from dry fermented sausage. Food Microbiology, 19, 441-449. http://dx.doi.org/10.1006/fmic.2002.0503.

Rantsiou, K., Iacumin, L., Cantoni, C., Comi, G., \& Cocolin, L. (2005). Ecology and characterization by molecular methods of Staphylococcus species isolated from fresh sausages. International Journal of Food Microbiology, 97, 277-284. http://dx.doi.org/10.1016/j.ijfoodmicro.2004.02.018.

Rodríguez, M., Núñez, F., Córdoba, J. J., Sanabria, C., Bermúdez, E., \& Asensio, M. A. (1994). Characterization of Staphylococcus spp. and Micrococcus spp. isolated from Iberian ham throughout the ripening process. International Journal of Food Microbiology, 24, 329-335. http://dx.doi.org/10.1016/0168-1605(94)90131-7.

Rodríguez Jovita, M. M. (1997). Evaluación tecnológica y sanitaria de las micrococáceas en la maduración del jamón de cerdo Ibérico. In. J. Ventanas (Ed.). Bases de la calidad del jamón Ibérico (pp. 107-129). Badajoz, Spain: Publicaciones de la Consejería de Agricultura y Comercio de la Junta de Extremadura.

Schleifer, K. H. (1986). Gram-positive cocci. In P.H.A. Sneath, N.S. Mair, M.E. Sharpe, \& J.G. Holtz (Eds.). Bergey's Manual of Systematic Bacteriology (pp. 999-1103). Baltimore, MD: The Williams and Wilkins Company.

Schleifer, K. H., Kilpper-Bälz, R., \& Devriese, L. A. (1984). Staphylococcus arletae spp. nov., S. equorum spp. nov and S. kloosii spp. nov: three new coagulase-negative, novobiocin-resistant species from animals. Systematic and Applied Microbiology, 5, 501-509.

Schleifer, K. H., \& Kloos, W. E. (1975a). A simple test system for the separation of staphylococci from micrococci. Journal of Clinical Microbiology, 1, 337-338.

Schleifer, K. H., \& Kloos, W. E. (1975b). Isolation and characterization of staphylococci from human skin. I. Amended descriptions of Staphylococcus epidermidis and S. saprophyticus and descriptions of three new species: S. cohnii, S. haemolyticus and S. xylosus. International Journal of Systematic Bacteriology, 25, 50-61.

Seager, M. S., Banks, J. G., De Blackburn, C. W., \& Board, R. G. (1986). A taxonomic study of Staphylococcus spp. isolated from fermented sausages. Journal of Food Science, 51, 295-297.

Silla, H., Molina, I., Flores, J., \& Silvestre, D. (1989). A study of the microbial flora of dry-cured ham. 1.

Isolation and growth. Fleischwirtschaft, 69, 1128-1131. 
Simonetti, P., \& Cantoni, C. (1983). Coagulase negative staphlylococci for dry sausage ripening. Industrie Alimentari, 22, 262-264.

Van der Riet, W. B. (1982). Biltong: a south African dried meat product. Fleischwirtschaft, 62, 1000-1001.

Veiga, A, Cobos, A., Ros, C., \& Díaz, O. (2003). Chemical and fatty acid composition of "Lacón gallego" (dry-cured pork foreleg): differences between external and internal muscles. Journal of Food Composition and Analysis, 16, 121-132. http://dx.doi.org/10.1016/S0889-1575(02)00162-X.

Vilar, I., García Fontán, M. C., Prieto, B., Tornadijo, M. E., \& Carballo, J. (2000). A survey on the microbiological changes during the manufacture of dry-cured lacón, a Spanish traditional meat product. Journal of Applied Microbiology, 89, 1018-1026. http://dx.doi.org/10.1046/j.1365-2672.2000.01210.x.

Von Rheinbaben, K. E., \& Seipp, H. (1986). Studies in the microflora of raw hams with special reference to Micrococcaceae. Chemie, Mikrobiologie, Technologie der Lebensmittel, 9, 152-161.

Table 1. Evolution of the counts (log CFU/g) in the different culture media on the surface and in the interior of the pieces during the manufacture of dry-cured lacón made without and with additives (data are the average \pm standard deviation of three batches in each manufacture type)

\begin{tabular}{|c|c|c|c|c|c|c|c|c|c|c|c|}
\hline & & & \multirow{2}{*}{ Fresh piece } & \multirow{2}{*}{$\begin{array}{l}\text { After } \\
\text { salting }\end{array}$} & \multicolumn{2}{|c|}{ Post-salting (days) } & \multicolumn{5}{|c|}{ Drying-ripening (days) } \\
\hline & & & & & 7 & 14 & 7 & 14 & 28 & 56 & 84 \\
\hline \multirow{4}{*}{ 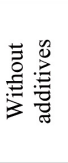 } & \multirow{2}{*}{ SPC agar } & Surface & $6.71 \pm 0.44^{\mathrm{ab}}$ & $5.93 \pm 0.76^{\mathrm{a}}$ & $5.56 \pm 0.44^{\mathrm{a}}$ & $7.51 \pm 0.96^{\mathrm{bc}}$ & $8.45 \pm 0.73^{\mathrm{cd}}$ & $9.29 \pm 0.17^{\mathrm{d}}$ & $9.27 \pm 0.27^{\mathrm{d}}$ & $9.13 \pm 0.31^{\mathrm{d}}$ & $9.26 \pm 0.33^{\mathrm{d}}$ \\
\hline & & Interior & $3.51 \pm 0.38^{\text {acde }}$ & $0.57 \pm 0.99^{\mathrm{b}}$ & $1.26 \pm 1.10^{\mathrm{abc}}$ & $3.27 \pm 1.64^{\mathrm{abcde}}$ & $3.53 \pm 1.25^{\mathrm{cde}}$ & $2.99 \pm 2.64^{\text {abcde }}$ & $4.19 \pm 1.14^{\mathrm{de}}$ & $1.59 \pm 1.39^{\mathrm{abcd}}$ & $4.40 \pm 0.90^{\mathrm{e}}$ \\
\hline & \multirow{2}{*}{$\begin{array}{l}\text { SPC agar + } \\
7.5 \% \mathrm{NaCl}\end{array}$} & Surface & $4.56 \pm 1.51^{\mathrm{a}}$ & $3.99 \pm 0.63^{\mathrm{a}}$ & $4.24 \pm 0.43^{\mathrm{a}}$ & $6.39 \pm 2.64^{b}$ & $8.43 \pm 0.77^{\mathrm{c}}$ & $9.28 \pm 0.17^{\mathrm{c}}$ & $9.33 \pm 0.33^{\mathrm{c}}$ & $9.22 \pm 0.23^{\mathrm{c}}$ & $9.31 \pm 0.25^{\mathrm{c}}$ \\
\hline & & Interior & $1.91 \pm 1.06^{\mathrm{ab}}$ & - & $1.63 \pm 0.46^{\mathrm{ab}^{*}}$ & $2.71 \pm 2.37^{\mathrm{b}}$ & $3.49 \pm 1.32^{\mathrm{b}}$ & $2.97 \pm 2.62^{\mathrm{b}}$ & $4.03 \pm 1.21^{\mathrm{b}}$ & $1.64 \pm 1.43^{\mathrm{a}^{*}}$ & $3.60 \pm 1.35^{\mathrm{b}}$ \\
\hline \multirow{4}{*}{ 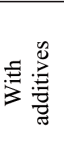 } & \multirow{2}{*}{ SPC agar } & Surface & $7.04 \pm 1.75^{\mathrm{a}}$ & $5.60 \pm 0.94^{b}$ & $5.47 \pm 0.49^{\mathrm{b}}$ & $6.55 \pm 1.47^{\mathrm{ab}}$ & $8.60 \pm 0.48^{\mathrm{c}}$ & $8.85 \pm 0.21^{\mathrm{c}}$ & $9.41 \pm 0.02^{\mathrm{c}}$ & $9.24 \pm 0.30^{\mathrm{c}}$ & $8.37 \pm 0.88^{\mathrm{c}}$ \\
\hline & & Interior & $2.88 \pm 2.75^{\mathrm{ab}}$ & $0.89 \pm 1.54^{\mathrm{a}}$ & $2.23 \pm 2.52^{\mathrm{ab}}$ & $2.89 \pm 2.63^{\mathrm{ab}}$ & $3.99 \pm 0.81^{b}$ & $3.76 \pm 0.94^{b}$ & $4.46 \pm 1.12^{\mathrm{b}}$ & $4.25 \pm 0.36^{b}$ & $2.92 \pm 2.53^{\mathrm{ab}}$ \\
\hline & \multirow{2}{*}{$\begin{array}{l}\text { SPC agar + } \\
7.5 \% \mathrm{NaCl}\end{array}$} & Surface & $4.36 \pm 1.09^{\mathrm{ab}}$ & $3.88 \pm 0.95^{\mathrm{a}}$ & $4.12 \pm 0.73^{\mathrm{ab}}$ & $5.70 \pm 2.19^{\mathrm{b}}$ & $8.58 \pm 0.54^{\mathrm{c}}$ & $8.83 \pm 0.27^{\mathrm{c}}$ & $9.39 \pm 0.05^{\mathrm{c}}$ & $9.29 \pm 0.24^{\mathrm{c}}$ & $8.39 \pm 0.88^{\mathrm{c}}$ \\
\hline & & Interior & $1.43 \pm 1.65^{\mathrm{ab}}$ & - & $1.74 \pm 1.64^{\mathrm{abd}^{*}}$ & $2.59 \pm 2.57^{\mathrm{bcd}}$ & $3.66 \pm 0.38^{\mathrm{bcd}}$ & $3.80 \pm 0.95^{\mathrm{bcd}}$ & $4.42 \pm 1.19^{\mathrm{cd}}$ & $4.16 \pm 0.31^{\mathrm{d}^{*}}$ & $2.46 \pm 2.30^{\mathrm{abcd}}$ \\
\hline
\end{tabular}

a-e Values in the same row (corresponding to the same culture media and location in the piece) not followed by a common letter differ significantly $(P<0.05)$.

${ }^{*}$ Values which were significantly different $(P<0.05)$ in that sampling point when batches made without additives were compared with those made with additives.

- = Absence in $0.2 \mathrm{~g}$. 
Table 2. Values of some physico-chemical parameters during the manufacture process of dry-cured lacón made without and with additives (average values \pm standard deviations of three batches in each manufacture type)

\begin{tabular}{|c|c|c|c|c|c|c|c|c|c|c|c|}
\hline & & & \multirow{2}{*}{ Fresh piece } & \multirow{2}{*}{ After salting } & \multicolumn{2}{|c|}{ Post-salting (days) } & \multicolumn{5}{|c|}{ Drying-ripening (days) } \\
\hline & & & & & 7 & 14 & 7 & 14 & 28 & 56 & 84 \\
\hline \multirow{10}{*}{ 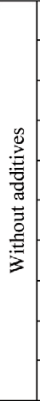 } & T. S. ${ }^{1}$ & Surface & $26.19 \pm 1.41^{\mathrm{a}}$ & $37.00 \pm 4.68^{b}$ & $38.56 \pm 0.10^{b}$ & $48.16 \pm 2.44^{c}$ & $48.89 \pm 0.64^{c}$ & $62.34 \pm 5.72^{d}$ & $60.46 \pm 1.67^{d}$ & $64.54 \pm 3.04^{\mathrm{de}}$ & $69.07 \pm 0.37^{\mathrm{e}}$ \\
\hline & & Interior & $29.66 \pm 6.23^{\mathrm{a}}$ & $36.54 \pm 5.72^{b}$ & $36.95 \pm 5.16^{b}$ & $40.08 \pm 3.44^{\mathrm{bcd}}$ & $39.43 \pm 2.08^{\mathrm{bc}}$ & $43.90 \pm 4.40^{\mathrm{cd}}$ & $46.03 \pm 2.92^{\mathrm{dc}}$ & $51.09 \pm 2.97^{\mathrm{c}}$ & $57.98 \pm 2.81^{f}$ \\
\hline & $\mathrm{NaCl}^{2}$ & Surface & $0.45 \pm 0.03^{\mathrm{a}}$ & $23.37 \pm 2.75^{b}$ & $22.67 \pm 2.50^{\mathrm{b}}$ & $16.04 \pm 1.63^{c}$ & $14.77 \pm 2.11^{\mathrm{cd}}$ & $12.43 \pm 1.82^{\mathrm{cd}}$ & $12.06 \pm 3.82^{\mathrm{cd}}$ & $12.20 \pm 2.97^{\mathrm{cd}}$ & $10.99 \pm 2.24^{\mathrm{d}}$ \\
\hline & & Interior & $0.47 \pm 0.02^{\mathrm{a}}$ & $9.27 \pm 1.82^{\mathrm{b}}$ & $13.14 \pm 1.70^{\mathrm{b}}$ & $13.34 \pm 2.00^{\mathrm{b}}$ & $14.33 \pm 1.02^{b}$ & $12.76 \pm 3.38^{b}$ & $14.26 \pm 3.79^{\mathrm{b}}$ & $13.88 \pm 4.19^{\mathrm{b}}$ & $13.06 \pm 4.90^{\mathrm{b}}$ \\
\hline & $\mathrm{pH}$ & Surface & $6.08 \pm 0.02^{\mathrm{ac}}$ & $6.09 \pm 0.03^{\text {ac }}$ & $6.28 \pm 0.21^{\mathrm{abccd}}$ & $6.48 \pm 0.07^{\mathrm{bd}}$ & $6.19 \pm 0.32^{\mathrm{cd}}$ & $6.55 \pm 0.15^{\text {bd }}$ & $6.43 \pm 0.04^{\mathrm{d}}$ & $6.34 \pm 0.16^{\text {abcd }}$ & $6.33 \pm 0.23^{\text {abcd }}$ \\
\hline & & Interior & $6.36 \pm 0.27^{\mathrm{a}}$ & $6.17 \pm 0.22^{\mathrm{a}}$ & $6.22 \pm 0.06^{\mathrm{a}}$ & $6.24 \pm 0.21^{\mathrm{a}}$ & $6.16 \pm 0.16^{\mathrm{a}}$ & $6.34 \pm 0.24^{\mathrm{a}}$ & $6.25 \pm 0.07^{\mathrm{a}}$ & $6.25 \pm 0.09^{\mathrm{a}}$ & $6.40 \pm 0.22^{\mathrm{a}}$ \\
\hline & $\mathrm{a}_{\mathrm{w}}$ & Surface & $1.000 \pm 0.001^{\mathrm{a}}$ & $0.912 \pm 0.036^{\mathrm{b}}$ & $0.928 \pm 0.014^{\mathrm{b}}$ & $0.907 \pm 0.020^{b}$ & $0.904 \pm 0.010^{\mathrm{bc}}$ & $0.894 \pm 0.021^{\mathrm{bc}}$ & $0.834 \pm 0.057^{\mathrm{cd}}$ & $0.836 \pm 0.069^{\text {cd }}$ & $0.806 \pm 0.069^{\mathrm{d}}$ \\
\hline & & Interior & $0.997 \pm 0.003^{\mathrm{a}}$ & $0.968 \pm 0.003^{\mathrm{ab}}$ & $0.962 \pm 0.003^{\mathrm{ab}}$ & $0.951 \pm 0.015^{\mathrm{ab}}$ & $0.947 \pm 0.014^{\mathrm{bc}}$ & $0.944 \pm 0.016^{\mathrm{bc}}$ & $0.930 \pm 0.025^{\mathrm{bc}}$ & $0.900 \pm 0.059^{\mathrm{cd}}$ & $0.876 \pm 0.075^{\mathrm{d}}$ \\
\hline & Nitrate & $e^{3}$ Surface & $42.94 \pm 4.24^{\text {acd }}$ & $92.35 \pm 4.24^{\mathrm{b}^{*}}$ & $84.90 \pm 10.01^{\text {bd" }}$ & $70.00 \pm 9.63^{\text {bed }}$ & $58.24 \pm 13.87^{\mathrm{cd}^{*}}$ & $61.76 \pm 16.60^{\mathrm{d}^{x}}$ & $60.20 \pm 9.51^{c}$ & $50.39 \pm 11.90^{c^{*}}$ & $53.14 \pm 3.40^{c^{*}}$ \\
\hline & & Interior & $37.45 \pm 7.19^{\text {acd }}$ & $44.51 \pm 8.91^{\text {ad }}$ & $35.88 \pm 10.26^{\mathrm{abcd}^{*}}$ & $32.75 \pm 4.75^{\text {abcd }^{*}}$ & $37.06 \pm 4.24^{\text {acd }^{*}}$ & $33.53 \pm 3.11^{\mathrm{abcd}^{*}}$ & $24.12 \pm 3.53^{\mathrm{bc}^{*}}$ & $31.96 \pm 4.45^{\mathrm{cd}^{*}}$ & $39.02 \pm 6.04^{d^{d}}$ \\
\hline \multirow{10}{*}{ 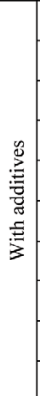 } & T.S. ${ }^{1}$ & Surface & $26.71 \pm 1.98^{\mathrm{a}}$ & $39.32 \pm 1.12^{b}$ & $41.59 \pm 0.78^{b}$ & $51.59 \pm 7.88^{\mathrm{c}}$ & $53.25 \pm 3.19^{c}$ & $63.82 \pm 3.84^{d}$ & $64.18 \pm 2.86^{\mathrm{d}}$ & $64.75 \pm 3.36^{\mathrm{de}}$ & $69.83 \pm 3.50^{e}$ \\
\hline & & Interior & $28.72 \pm 4.25^{\mathrm{a}}$ & $40.21 \pm 2.61^{b}$ & $40.45 \pm 3.53^{\mathrm{b}}$ & $38.73 \pm 2.25^{\mathrm{b}}$ & $42.18 \pm 5.21^{\mathrm{bc}}$ & $44.06 \pm 4.74^{\mathrm{bc}}$ & $48.00 \pm 3.23^{\mathrm{cd}}$ & $50.83 \pm 3.50^{\mathrm{de}}$ & $54.98 \pm 2.86^{\mathrm{e}}$ \\
\hline & $\mathrm{NaCl}^{2}$ & Surface & $0.46 \pm 0.03^{2}$ & $22.59 \pm 2.15^{b}$ & $20.05 \pm 1.68^{\mathrm{bc}}$ & $17.45 \pm 4.78^{\circ}$ & $16.14 \pm 4.24^{\mathrm{cd}}$ & $11.70 \pm 1.42^{\text {def }}$ & $10.87 \pm 2.37^{\text {ef }}$ & $12.74 \pm 3.57^{\mathrm{df}}$ & $11.64 \pm 3.39^{\mathrm{f}}$ \\
\hline & & Interior & $0.45 \pm 0.03^{\mathrm{a}}$ & $8.33 \pm 1.45^{b}$ & $11.06 \pm 1.59^{b}$ & $11.34 \pm 2.84^{\mathrm{b}}$ & $13.26 \pm 2.49^{b}$ & $13.35 \pm 3.50^{b}$ & $12.62 \pm 4.87^{\mathrm{b}}$ & $12.44 \pm 5.63^{\mathrm{b}}$ & $13.14 \pm 5.58^{b}$ \\
\hline & & Surface & $6.22 \pm 0.28^{\mathrm{abc}}$ & $6.06 \pm 0.16^{\mathrm{ac}}$ & $6.38 \pm 0.03^{\mathrm{bc}}$ & $6.49 \pm 0.01^{\mathrm{b}}$ & $6.12 \pm 0.33^{\mathrm{c}}$ & $6.34 \pm 0.14^{\text {abc }}$ & $6.23 \pm 0.08^{\text {abc }}$ & $6.44 \pm 0.10^{\mathrm{ab}}$ & $6.21 \pm 0.24^{\mathrm{abc}}$ \\
\hline & & Interior & $6.58 \pm 0.10^{\mathrm{a}}$ & $6.02 \pm 0.10^{\mathrm{bc}}$ & $6.32 \pm 0.21^{\mathrm{abc}}$ & $6.23 \pm 0.31^{\mathrm{bc}}$ & $6.20 \pm 0.19^{\mathrm{bc}}$ & $6.13 \pm 0.27^{\mathrm{bc}}$ & $6.26 \pm 0.07^{\mathrm{bc}}$ & $6.38 \pm 0.12^{\mathrm{c}}$ & $6.30 \pm 0.23^{\mathrm{abc}}$ \\
\hline & & Surface & $0.999 \pm 0.001^{\mathrm{a}}$ & $0.893 \pm 0.085^{\mathrm{h}}$ & $0.920 \pm 0.014^{\mathrm{h}}$ & $0.910 \pm 0.020^{\mathrm{h}}$ & $0.889 \pm 0.035^{\mathrm{h}}$ & $0.864 \pm 0.032^{\text {hec }}$ & $0.856 \pm 0.032^{\text {hed }}$ & $0.800 \pm 0.059^{\text {cdd }}$ & $0.787 \pm 0.051^{\mathrm{d}}$ \\
\hline & & Interior & $0.996 \pm 0.001^{\mathrm{a}}$ & $0.966 \pm 0.011^{\mathrm{ab}}$ & $0.956 \pm 0.016^{\mathrm{abc}}$ & $0.953 \pm 0.024^{\mathrm{abc}}$ & $0.945 \pm 0.023^{\mathrm{ef}}$ & $0.940 \pm 0.022^{\mathrm{bc}}$ & $0.928 \pm 0.037^{\mathrm{bcd}}$ & $0.910 \pm 0.034^{\mathrm{cd}}$ & $0.885 \pm 0.032^{\mathrm{d}}$ \\
\hline & Nitrate & Surface & $51.96 \pm 10.67^{\mathrm{a}}$ & $124.12 \pm 9.19^{\mathrm{bc}}$ & $115.10 \pm 6.79^{\text {bce }}$ & $131.57 \pm 30.23^{\mathrm{b}}$ & $124.12 \pm 18.93^{\mathrm{bc}}$ & $101.76 \pm 24.02^{\text {cdef }}$ & $78.63 \pm 9.87^{\mathrm{def}}$ & $92.75 \pm 22.08^{\mathrm{ef}}$ & $87.25 \pm 16.53^{\mathrm{f}}$ \\
\hline & & Interior & $47.25 \pm 7.83^{\mathrm{a}}$ & $50.39 \pm 5.56^{\mathrm{a}}$ & $85.69 \pm 5.31^{b}$ & $83.33 \pm 12.02^{b}$ & $88.04 \pm 1.36^{b}$ & $80.20 \pm 12.58^{\mathrm{bc}}$ & $76.27 \pm 8.83^{\mathrm{bc}}$ & $68.82 \pm 8.48^{\mathrm{c}}$ & $70.78 \pm 8.67^{\mathrm{c}}$ \\
\hline
\end{tabular}

${ }^{1}$ Total Solids (Expressed as $\left.\mathrm{g} / 100 \mathrm{~g}\right) ;{ }^{2}$ Expressed as $\mathrm{g} / 100 \mathrm{~g}$ of Total Solids; ${ }^{3}$ Expressed as ppm

${ }^{\mathrm{a}-\mathrm{f}}$ Values in the same row (corresponding to the same parameter and location in the piece) not followed by a common letter differ significantly $(P<0.05)$

* Values which were significantly different $(P<0.05)$ in that sampling point when compared the batches made without additives with those made with additives 
Table 3. Changes in the species isolated from SPC agar $+7.5 \% \mathrm{NaCl}$ from the surface and the interior of the pieces during the manufacture of dry-cured lacón made without additives (two batches)

\begin{tabular}{|c|c|c|c|c|c|c|c|c|c|c|c|c|c|c|c|c|c|c|c|c|c|}
\hline & \multirow{3}{*}{ Species } & \multirow{2}{*}{\multicolumn{2}{|c|}{ Fresh piece }} & \multirow{2}{*}{\multicolumn{2}{|c|}{ After salting }} & \multicolumn{4}{|c|}{ Post-salting (days) } & \multicolumn{10}{|c|}{ Drying-ripening (days) } & \multirow{2}{*}{\multicolumn{2}{|c|}{ Total }} \\
\hline & & & & & & \multicolumn{2}{|l|}{7} & \multicolumn{2}{|c|}{14} & \multicolumn{2}{|l|}{7} & \multicolumn{2}{|c|}{14} & \multicolumn{2}{|c|}{28} & \multicolumn{2}{|c|}{56} & \multicolumn{2}{|c|}{84} & & \\
\hline & & $\begin{array}{l}\mathrm{N}^{\circ} \text { of } \\
\text { strains }\end{array}$ & $\%$ & $\begin{array}{l}\mathrm{N}^{\circ} \text { of } \\
\text { strains }\end{array}$ & $\%$ & $\begin{array}{c}\mathrm{N}^{\circ} \text { of } \\
\text { strains }\end{array}$ & $\%$ & $\begin{array}{l}\mathrm{N}^{\circ} \text { of } \\
\text { strains }\end{array}$ & $\%$ & $\begin{array}{l}\mathrm{N}^{0} \text { of } \\
\text { strains }\end{array}$ & $\%$ & $\begin{array}{l}\mathrm{N}^{\circ} \text { of } \\
\text { strains }\end{array}$ & $\%$ & $\begin{array}{l}\mathrm{N}^{\circ} \text { of } \\
\text { strains }\end{array}$ & $\%$ & $\begin{array}{l}\mathrm{N}^{\circ} \text { of } \\
\text { strains }\end{array}$ & $\%$ & $\begin{array}{l}\mathrm{N}^{\circ} \text { of } \\
\text { strains }\end{array}$ & $\%$ & $\begin{array}{l}\mathrm{N}^{\circ} \text { of } \\
\text { strains }\end{array}$ & $\%$ \\
\hline \multirow{13}{*}{ 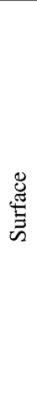 } & Staph. xylosus & 2 & 20 & 1 & 10 & 10 & 100 & 6 & 60 & 7 & 70 & 7 & 70 & 5 & 50 & 8 & 80 & 6 & 60 & 52 & 57.78 \\
\hline & Staph. equorum & 0 & 0 & 1 & 10 & 0 & 0 & 2 & 20 & 0 & 0 & 0 & 0 & 1 & 10 & 0 & 0 & 1 & 10 & 5 & 5.55 \\
\hline & Staph. warneri & 0 & 0 & 0 & 0 & 0 & 0 & 0 & 0 & 0 & 0 & 0 & 0 & 0 & 0 & 1 & 10 & 0 & 0 & 1 & 1.11 \\
\hline & Staph. epidermidis & 0 & 0 & 0 & 0 & 0 & 0 & 0 & 0 & 0 & 0 & 1 & 10 & 0 & 0 & 0 & 0 & 0 & 0 & 1 & 2.22 \\
\hline & Staph. intermedius & 0 & 0 & 1 & 10 & 0 & 0 & 0 & 0 & 2 & 20 & 2 & 20 & 1 & 10 & 0 & 0 & 1 & 10 & 7 & 5.55 \\
\hline & Staph. capitis & 0 & 0 & 0 & 0 & 0 & 0 & 0 & 0 & 1 & 10 & 0 & 0 & 0 & 0 & 0 & 0 & 1 & 10 & 2 & 2.22 \\
\hline & Staph. sciuri & 0 & 0 & 2 & 20 & 0 & 0 & 0 & 0 & 0 & 0 & 0 & 0 & 0 & 0 & 0 & 0 & 0 & 0 & 2 & 2.22 \\
\hline & Staph. gallinarum & 0 & 0 & 1 & 10 & 0 & 0 & 0 & 0 & 0 & 0 & 0 & 0 & 0 & 0 & 0 & 0 & 0 & 0 & 1 & 1.11 \\
\hline & Kocuria varians & 1 & 10 & 0 & 0 & 0 & 0 & 0 & 0 & 0 & 0 & 0 & 0 & 1 & 10 & 0 & 0 & 0 & 0 & 2 & 2.22 \\
\hline & Micrococcus lylae & 0 & 0 & 0 & 0 & 0 & 0 & 0 & 0 & 0 & 0 & 0 & 0 & 0 & 0 & 1 & 10 & 0 & 0 & 1 & 1.11 \\
\hline & $\begin{array}{l}\text { No Micrococcaceae or } \\
\text { Staphylococcaceae }\end{array}$ & 7 & 70 & 2 & 20 & 0 & 0 & 2 & 20 & 0 & 0 & 0 & 0 & 0 & 0 & 0 & 0 & 0 & 0 & 11 & 12.22 \\
\hline & Isolates lost & 0 & 0 & 2 & 20 & 0 & 0 & 0 & 0 & 0 & 0 & 0 & 0 & 2 & 20 & 0 & 0 & 1 & 10 & 5 & 5.55 \\
\hline & Total isolates & 10 & 100 & 10 & 100 & 10 & 100 & 10 & 100 & 10 & 100 & 10 & 100 & 10 & 100 & 10 & 100 & 10 & 100 & 90 & 100 \\
\hline \multirow{12}{*}{ 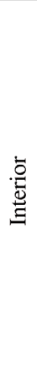 } & Staph. xylosus & 2 & 20 & 0 & 0 & 6 & 60 & 6 & 60 & 7 & 70 & 9 & 90 & 10 & 100 & 10 & 100 & 6 & 60 & 56 & 70 \\
\hline & Staph. equorum & 0 & 0 & 0 & 0 & 1 & 10 & 2 & 20 & 0 & 0 & 0 & 0 & 0 & 0 & 0 & 0 & 0 & 0 & 3 & 3.75 \\
\hline & Staph. simulans & 1 & 10 & 0 & 0 & 0 & 0 & 0 & 0 & l & 10 & 0 & 0 & 0 & 0 & 0 & 0 & 0 & 0 & 2 & 2.5 \\
\hline & Staph. intermedius & 0 & 0 & 0 & 0 & 0 & 0 & 0 & 0 & 0 & 0 & 0 & 0 & 0 & 0 & 0 & 0 & 1 & 10 & 1 & 1.25 \\
\hline & Staph. capitis & 0 & 0 & 0 & 0 & 1 & 10 & 0 & 0 & 0 & 0 & 0 & 0 & 0 & 0 & 0 & 0 & 0 & 0 & 1 & 1.25 \\
\hline & Staph. cohnii & 0 & 0 & 0 & 0 & 1 & 10 & 0 & 0 & 0 & 0 & 0 & 0 & 0 & 0 & 0 & 0 & 0 & 0 & 1 & 1.25 \\
\hline & Staph. gallinarum & 0 & 0 & 0 & 0 & 1 & 10 & 0 & 0 & 0 & 0 & 0 & 0 & 0 & 0 & 0 & 0 & 0 & 0 & 1 & 1.25 \\
\hline & Kocuria varians & 1 & 10 & 0 & 0 & 0 & 0 & 1 & 10 & 0 & 0 & 0 & 0 & 0 & 0 & 0 & 0 & 0 & 0 & 2 & 2.5 \\
\hline & Kocuria rosea & 0 & 0 & 0 & 0 & 0 & 0 & 0 & 0 & 0 & 0 & 0 & 0 & 0 & 0 & 0 & 0 & 1 & 10 & 1 & 1.25 \\
\hline & $\begin{array}{l}\text { No Micrococcaceae or } \\
\text { Staphylococcaceae }\end{array}$ & 6 & 60 & 0 & 0 & 0 & 0 & 1 & 10 & 1 & 10 & 1 & 10 & 0 & 0 & 0 & 0 & 2 & 20 & 11 & 13.75 \\
\hline & Isolates lost & 0 & 0 & 0 & 0 & 0 & 0 & 0 & 0 & 1 & 10 & 0 & 0 & 0 & 0 & 0 & 0 & 0 & 0 & 1 & 1.25 \\
\hline & Total isolates & 10 & 100 & 0 & 0 & 10 & 100 & 10 & 100 & 10 & 100 & 10 & 100 & 10 & 100 & 10 & 100 & 10 & 100 & 80 & 100 \\
\hline
\end{tabular}

Table 4. Changes in the species isolated from SPC agar $+7.5 \% \mathrm{NaCl}$ from the surface and the interior of the pieces during the manufacture of dry-cured lacón made with additives (two batches)

\begin{tabular}{|c|c|c|c|c|c|c|c|c|c|c|c|c|c|c|c|c|c|c|c|c|c|}
\hline & \multirow{3}{*}{ Species } & \multirow{2}{*}{\multicolumn{2}{|c|}{ Fresh piece }} & \multirow{2}{*}{\multicolumn{2}{|c|}{ After salting }} & \multicolumn{4}{|c|}{ Post-salting (days) } & \multicolumn{10}{|c|}{ Drying-ripening (days) } & \multirow{2}{*}{\multicolumn{2}{|c|}{ Total }} \\
\hline & & & & & & \multicolumn{2}{|c|}{7} & \multicolumn{2}{|c|}{14} & \multicolumn{2}{|l|}{7} & \multicolumn{2}{|l|}{14} & \multicolumn{2}{|l|}{28} & \multicolumn{2}{|c|}{56} & \multicolumn{2}{|l|}{84} & & \\
\hline & & \begin{tabular}{|l|}
$\mathrm{N}^{\circ}$ of \\
strains
\end{tabular} & $\%$ & $\begin{array}{l}\mathrm{N}^{\circ} \text { of } \\
\text { strains }\end{array}$ & $\%$ & $\begin{array}{l}\mathrm{N}^{\circ} \text { of } \\
\text { strains }\end{array}$ & $\%$ & $\begin{array}{l}N^{\circ} \text { of } \\
\text { strains }\end{array}$ & $\%$ & \begin{tabular}{|c|}
$\mathrm{N}^{\circ}$ of \\
strains
\end{tabular} & $\%$ & \begin{tabular}{|c|}
$\mathrm{N}^{\circ}$ of \\
strains
\end{tabular} & $\%$ & \begin{tabular}{|c|}
$\mathrm{N}^{\circ}$ of \\
strains
\end{tabular} & $\%$ & \begin{tabular}{|c|}
$N^{\circ}$ of \\
strains
\end{tabular} & $\%$ & \begin{tabular}{|c|}
$N^{\circ}$ of \\
strains
\end{tabular} & $\%$ & \begin{tabular}{c|}
$\mathrm{N}^{\circ}$ of \\
strains
\end{tabular} & $\%$ \\
\hline \multirow{13}{*}{ 总 } & Staph. xylosus & 1 & 10 & 7 & 70 & 6 & 60 & 9 & 90 & 7 & 70 & 3 & 30 & 6 & 60 & 9 & 90 & 8 & 80 & 56 & 62.23 \\
\hline & Staph. equorum & 0 & 0 & 0 & 0 & 1 & 10 & 1 & 10 & 1 & 10 & 1 & 10 & 0 & 0 & 0 & 0 & 0 & 0 & 4 & 4.44 \\
\hline & Staph. warneri & 0 & 0 & 0 & 0 & 1 & 10 & 0 & 0 & 1 & 10 & 0 & 0 & 0 & 0 & 0 & 0 & 0 & 0 & 2 & 2.22 \\
\hline & Staph. epidermidis & 0 & 0 & 1 & 10 & 1 & 10 & 0 & 0 & 0 & 0 & 0 & 0 & 0 & 0 & 0 & 0 & 1 & 10 & 3 & 3.33 \\
\hline & Staph. intermedius & 0 & 0 & 0 & 0 & 0 & 0 & 0 & 0 & 1 & 10 & 3 & 30 & 0 & 0 & 0 & 0 & 0 & 0 & 4 & 4.44 \\
\hline & Staph. capitis & 1 & 10 & 0 & 0 & 0 & 0 & 0 & 0 & 0 & 0 & 3 & 30 & 1 & 10 & 0 & 0 & 0 & 0 & 5 & 5.55 \\
\hline & Staph. sciuri & 1 & 10 & 1 & 10 & 0 & 0 & 0 & 0 & 0 & 0 & 0 & 0 & 0 & 0 & 0 & 0 & 1 & 10 & 3 & 3.33 \\
\hline & Micrococcus luteus & 0 & 0 & 0 & 0 & 0 & 0 & 0 & 0 & 0 & 0 & 0 & 0 & 1 & 10 & 0 & 0 & 0 & 0 & 1 & 1.11 \\
\hline & Kocuria varians & 1 & 10 & 0 & 0 & 0 & 0 & 0 & 0 & 0 & 0 & 0 & 0 & 0 & & 0 & 0 & 0 & 0 & 1 & 1.11 \\
\hline & Kocuria rosea & 0 & 0 & 0 & 0 & 0 & 0 & 0 & 0 & 0 & 0 & 0 & 0 & 1 & 0 & 0 & 0 & 0 & 0 & 1 & 1.11 \\
\hline & $\begin{array}{l}\text { No Micrococcaceae or } \\
\text { Staphylococcaceae }\end{array}$ & 4 & 40 & 1 & 10 & 0 & 0 & 0 & 0 & 0 & 0 & 0 & 0 & 1 & 10 & 0 & 0 & 0 & 0 & 6 & 6.66 \\
\hline & Isolates lost & 2 & 20 & 0 & 0 & 1 & 10 & 0 & 0 & 0 & 0 & 0 & 0 & 0 & 0 & 1 & 10 & 0 & 0 & 4 & 4.44 \\
\hline & Total isolates & 10 & 100 & 10 & 100 & 10 & 100 & 10 & 100 & 10 & 100 & 10 & 100 & 10 & 100 & 10 & 100 & 10 & 100 & 90 & 100 \\
\hline \multirow{11}{*}{ 总 } & \begin{tabular}{|l} 
Staph. xylosus \\
\end{tabular} & 0 & 0 & 0 & 0 & 5 & 50 & 8 & 80 & 8 & 80 & 7 & 70 & 9 & \begin{tabular}{|l|}
90 \\
\end{tabular} & 8 & 80 & 6 & 60 & 51 & 68 \\
\hline & Staph. equorum & 0 & 0 & 0 & 0 & 0 & 0 & 0 & 0 & 0 & 0 & 1 & 10 & 0 & 0 & 0 & 0 & 1 & 10 & 2 & 2.67 \\
\hline & Staph. simulans & 0 & 0 & 0 & 0 & 0 & 0 & 0 & 0 & 0 & 0 & 0 & 0 & 1 & 10 & 0 & 0 & 0 & 0 & 1 & 1.33 \\
\hline & Staph. intermedius & 0 & 0 & 0 & 0 & 2 & 20 & 1 & 10 & 0 & 0 & 1 & 10 & 0 & 0 & 1 & 10 & 0 & 0 & 5 & 6.67 \\
\hline & Staph. capitis & 0 & 0 & 0 & 0 & 0 & 0 & 0 & 0 & 0 & 0 & 0 & 0 & 0 & 0 & 1 & 10 & 0 & 0 & 1 & 1.33 \\
\hline & Staph. cohnii & 0 & 0 & 0 & 0 & 1 & 10 & 0 & 0 & 0 & 0 & 0 & 0 & 0 & 0 & 0 & 0 & 0 & 0 & 1 & 1.33 \\
\hline & Staph. sciuri & 0 & 0 & 0 & 0 & 0 & 0 & 0 & 0 & 0 & 0 & 1 & 10 & 0 & 0 & 0 & 0 & 0 & 0 & 1 & 1.33 \\
\hline & Kocuria varians & 0 & 0 & 0 & 0 & 1 & 10 & 0 & 0 & 0 & 0 & 0 & 0 & 0 & 0 & 0 & 0 & 0 & 0 & 1 & 1.33 \\
\hline & $\begin{array}{l}\text { No Micrococcaceae or } \\
\text { Staphylococcaceae }\end{array}$ & 5 & 100 & 0 & 0 & 0 & 0 & 0 & 0 & 1 & 10 & 0 & 0 & 0 & 0 & 0 & 0 & 3 & 30 & 9 & 12 \\
\hline & Isolates lost & 0 & 0 & 0 & 0 & 1 & 10 & 1 & 10 & 1 & 10 & 0 & 0 & 0 & 0 & 0 & 0 & 0 & 0 & 3 & 4 \\
\hline & Total isolates & 5 & 100 & 0 & 0 & 10 & 100 & 10 & 100 & 10 & 100 & 10 & 100 & 10 & 100 & 10 & 100 & 10 & 100 & 75 & 100 \\
\hline
\end{tabular}

